\title{
The Age of The Surgeon: How Old Is Too Old?
}

\section{A Idade do Cirurgião: Quando é Demasiado Velho?}

Manuel J. ANTUNES $\square^{1,2}$

Acta Med Port 2019 Jun;32(6):413-414 - https://doi.org/10.20344/amp.12160

Keywords: Ageism; Clinical Competence; Surgeons

Palavras-chave: Ageismo; Cirurgiões; Competência Clínica

\section{INTRODUCTION}

One of the editors of Acta Médica Portuguesa (AMP) challenged me to look at the subject of the "age limit of the surgeon, at a time when surgical activity is undergoing technological revolution, with the implementation of minimally invasive approaches, with the rise of robotic surgery and with the promise of artificial intelligence applications."

The 70-year age limit for public sector workers in Portugal (not just physicians and / or surgeons), was set almost a century ago, more precisely by the Decree 16563 of $1929 .{ }^{1}$ This piece of legislation highlights the quality of work, "which is only exceptionally found in officials who have passed a certain 'age limit' and the spirit of initiative that disappears to give way to routine". Well, quality of work and initiative are two of the most important and essential qualities of a surgeon, and so if there were any reasons to keep this age limit in any group, it would be in our profession.

But the fact is that there has been substantial change in the past 90 years, especially since the longevity of Portuguese people has risen by about 15 years in the last five decades alone. ${ }^{2}$ On the other hand, the aging process and its manifestations are very variable from individual to individual. We all know one or another still active colleague who already shows significant physical impairment, although in some cases, with a well-functioning 'brain'. Hence, the answer to the question put to me, which is the title of this article, is impossible to answer.

In any case, the law was recently amended (Decree $6 / 2019$, of 14 January) ${ }^{3}$ and now allows the extension of the limit up to 75 years in "exceptional" and adequately justified cases, including "leadership positions". Curiously, the preamble of this new piece of legislation refers to "the need for the transfer of knowledge by workers at that age (70 years), if they choose to remain in active professional life, which may translate into added value to the regular functioning of the services, also fostering a harmonious and good quality professional environment, promoting the transfer of experience and knowledge between workers of different generations, with the aim of fostering good practices and know- how." The differences between the 1929 and the 2019 texts are very obvious.

Evidently, this law is not directed solely at the surgeons in public service but I cannot agree more with those who think that "organizations should take advantage of the aggregate experience of their senior professionals, allowing them to continue, if appropriate, to perform an adequate number of procedures, perhaps less complex, without interfering in the productivity and satisfaction of their younger colleagues". In fact, "the cumulative wisdom and clinical experience of the senior surgeon is an invaluable asset that must be honoured and maintained" ${ }^{4}$ I should point out that the invitation I received from the journal to write this Editorial mentioned that "however (despite technological developments), there is certainly room for the sharing of experience, clinical decision-making, and technical excellence that an end-of-career surgeon is acquiring and perfecting, in a training perspective of future generations".

\section{Anatomy of the problem}

A high sense of value and satisfaction experienced during active clinical practice is cited as the most common reason why surgeons continue to practice. The question is, therefore, whether there is any age beyond which the surgeon's age becomes an unacceptable part of the surgical risk. Dr Michael DeBakey, a pioneer of cardiac surgery, said at the age of 91: "I wouldn't mind being operated on by a 91-year-old surgeon!" Several surveys among surgeons have shown that there is no consensus in favour of a mandatory retirement age, leaving the decision to the individual.

It is clear that this subject should not be placed on a mere chronological scale or on a metric of skills and/or results, although these should certainly be considered when assessing a surgeon's physical and intellectual capacity to remain in practice. The problem is, still, about who would be able to say enough is enough. I doubt it should be up to the surgeon to decide, unless obliged to do so by obvious physical incapacity to stand for a few hours during an operation. I often say that a drunk never recognizes that

\footnotetext{
1. Cardiothoracic Surgeon. Coimbra. Portugal.

2. Emeritus Professor. Faculty of Medicine. University of Coimbra. Coimbra. Portugal.

$\square$ Autor correspondente: Manuel J. Antunes. mjantunes48@sapo.pt

Recebido: 06 de abril de 2019 - Aceite: 09 de abril de 2019 | Copyright @ Ordem dos Médicos 2019
} 
he is drunk and I have never heard a fool say he is a fool! Senility, which comes to us all, has exactly the same property of refraining us from making adequate judgments. And this can become very dangerous, especially for the patient, although, for most procedures, the surgeon's age is a poor prognostic predictor of operative risk. ${ }^{5}$

A very recent American study involving 892187 patients who were operated on urgently by 45826 surgeons demonstrated that the technical skills of surgeons increase with age even beyond the 60 's. ${ }^{6}$ The first functionality that declines with age is physical capacity, then vision, then dexterity and finally cognition. However, knowledge, experience and reputation can make up for those declines for a long time. But gradually decreasing the volume of complex procedures may result in a deterioration of the skills necessary for safe surgery, suggesting that an 'all or none' approach to complex procedures may be the most adequate in order to maintain a safe practice. ${ }^{7}$

\section{So how to identify the limit?}

Commercial aviation pilots cannot remain in command after a certain age, 65 years in Europe and the United States, and in both cases, even pilots under the maximum age undergo frequent medical examinations and performance tests according to protocols to ensure retention of a safe level of skills. Making a comparison with surgeons may not be entirely appropriate. After all, a pilots' responsibility will be even greater, but it is impossible not to draw parallels.

In Portugal, most surgeons that have retired from public practice, due to age limit or not, continue surgical activity in private practice, where supervision is even more difficult. We all know surgeons who extend their activity to the 80's

\section{REFERENCES}

1. Decreto n. ${ }^{\circ} 16563$ de 5 de Março de 1929. Diário do Govêrno n. ${ }^{\circ}$ 52/1929, Série I de 1929-03-05. p. 607-8.

2. PORDATA: base de dados de Portugal contemporâneo. [accessed 2019 May 30]. Available from: https://www.pordata.pt/Portugal/Esperan\%C3\% A7a+de+vida+\%C3\%A0+nascen $\%$ C3\%A7a+total+e+por+sexo+(base+ tri\%C3\%A9nio+a+partir+de+2001)-418.

3. Decreto-Lei n. ${ }^{\circ}$ 6/2019 de 14 de Janeiro de 2019. Diário da República n. ${ }^{\circ}$ /2019, I Série de 2019-01-14. p. 121-4.

4. Blasier RB. The problem of the aging surgeon. When surgeon age becomes a surgical risk factor. Clin Orthop Relat Res. 2009;467:402-11.

5. Bieliauskaus LA, Langenecker SA, Graver C, Jin Lee H, O'Neill J, and beyond! So how do you determine if someone is no longer capable of using the scalpel? It is obvious that, under these conditions, someone has to help the elderly surgeon make the decision. A program of the Sinai Hospital in Baltimore, USA, created in 2014 by Dr Mark Katlic, offers a two-day series of assessments of "physical and cognitive" functions for older surgeons. ${ }^{8}$ Apparently, no one has yet resorted to it!

But there are alternatives: for instance, another surgeon who is part of the team, the anaesthesiologist, the table nurse - they are the best observers of the quality of the surgeon. In my mind, there is no harm in asking trainees to warn us if they notice that something is not right. Certainly, in extreme cases, it is up to others in the team, no matter where in the surgical hierarchy, to raise the need to reassess a surgeon to the competent authority. In the end, the family may even be able to help: the action of shaking when holding the scalpel, scissors or forceps is naturally reproduced when grabbing cutlery or the glass during a meal. And episodes of obnubilation or confusion are even more evident in other day-to-day activities.

In conclusion, determining an age limit for a surgeon to stay active in the operating room is difficult and will vary from individual to individual. More than the chronological age, what counts is the functional age. ${ }^{9}$ As Mark Katlic stated, "we all know 80-year-olds who can play an intense game of tennis and others who cannot even walk to the mailbox". Fortunately, there are still many who have a clear sense of self-assessment and give up before they start hurting someone. However, it is up to each one of us to ensure that our own cognitive decline will not affect the awareness of our own limits.

Greenfield LJ. Cognitive changes and retirement among senior surgeons (CCRASS): results from the CCRASS study. J Am Coll Surg. 2008;69-79.

6. Tsugawa Y, Jena AB, Orav EJ, Blumenthal DM, Tsai TC, Mehtsun WT, et al. Age and sex of surgeons and mortality of older surgical patients: observational study. BMJ. 2018;361:k1343.

7. Waljee JF, Greenfield LJ, Dimick JB, Birkmeyer JD. Surgeon age and operative mortality in the United States. Ann Surg. 2006;244:353-62.

8. Katlic M, Coleman J. The aging surgeon. Ann Surg. 2014;260:199-201.

9. Katlic MR, Coleman JA, Russel MM. Assessing the performance of aging surgeons. JAMA. 2019;321:449-50. 